Check for updates

Cite this: RSC Adv., 2017, 7, 34699

Received 25th January 2017

Accepted 22nd June 2017

DOI: $10.1039 / c 7 r a 01111 c$

rsc.li/rsc-advances

\section{Evaluation of the anti-inflammatory properties of telmesteine on inflammation-associated skin diseases $\dagger$}

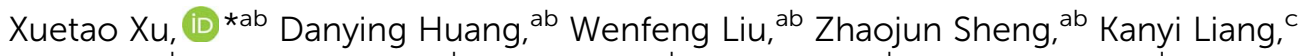 \\ Dongli Li, ${ }^{\text {ab }}$ Denggao Zhao, ${ }^{\text {ab }}$ Yanyan Ma, ${ }^{\text {ab }}$ Kun Zhang, ${ }^{\text {ab }}$ Tasawar Hayat, ${ }^{\text {de }}$ \\ Njud S. Alharbif and Weikuai Li ${ }^{* g}$
}

\begin{abstract}
Telmesteine, a useful agent for respiratory tract disorders, has been reported to be a critical active ingredient in topical compositions for dermatitis. The present study was designed to elucidate the in vitro and in vivo anti-inflammatory properties of telmesteine. LPS-induced NO production in RAW264.7 cells was significantly decreased after telmesteine treatment. TPA-induced skin inflammation as assessed by skin edema and pro-inflammatory cytokines (IL-1 $\beta, I L-6$, and TNF- $\alpha$ ) was significantly decreased after telmesteine topical treatment. Further analysis results demonstrated that the anti-inflammation properties of telmesteine were associated with its ability to inhibit activation of nuclear factor kappa- $\kappa \mathrm{B}$

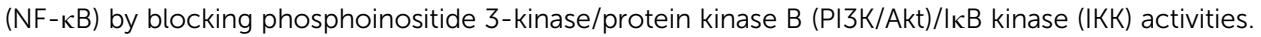

\section{Introduction}

Skin is the inherent barrier between the human body and the environment and one of its major functions is to defend the body from various intrinsic or extrinsic stimuli. ${ }^{1}$ When stimulated, the structure and function of skin are changed, which is usually translated into inflammation. ${ }^{2}$ It has been established that inflammation is associated with various skin diseases such as atopic dermatitis, psoriasis, rosacea, and cancer. ${ }^{3}$ Inflammation is a complex pathophysiological process. ${ }^{4,5}$ Various signaling molecules produced by activated leukocytes and nuclear factor- $\kappa \mathrm{B}(\mathrm{NF}-\kappa \mathrm{B})$ have a critical role in the inflammatory process. ${ }^{6,7}$

The mouse skin model has been widely used to study the molecular changes implicated in skin disease. 12-OTetradecanoylphorbol-13-acetate (TPA), a potent tumor promoter, induces skin inflammation, edema, and epidermal hyperplasia. ${ }^{\mathbf{8} 9}$ Topical application of TPA on mouse skin upregulates the gene expression of proliferation and

${ }^{a}$ School of Chemical and Environment Engineering, Wuyi University, Jiangmen, 529020, China.E-mail: wyuchemxxt@126.com

${ }^{b}$ International Healthcare Innovation Institute (Jiangmen), Jiangmen, 529000, China 'Faculté des Sciences et Techniques, Université du Maine Avenue Olivier Messiaen, 72085 Le Mans Cedex 9, France

${ }^{d}$ Department of Mathematics, Quaid-I-Azam University, Islamabad 44000, Pakistan ${ }^{e}$ NAAM Research Group, King Abdulaziz University, Jeddah, Saudi Arabia

${ }^{f}$ Biotechnology Research Group, Department of Biological Sciences, Faculty of Science, King Abdulaziz University, Jeddah, Saudi Arabia

${ }^{g}$ Suzhou Pharmpower Topical Research Labratory Co. Ltd., Suzhou, 215000, China

$\dagger$ Electronic supplementary information (ESI) available. See DOI: 10.1039/c7ra01111c inflammation including cyclooxygenase (COX-2), inducible nitric oxide synthase (iNOS), and ODC. Experimental evidence has shown that TPA induces inflammatory expression by the activation of $N F-\kappa B$, through activation of inhibitor $\kappa \mathrm{B}(\mathrm{I} \kappa \mathrm{B})$ kinases. Up-regulation of phosphatidylinositol 3-kinase (PI3K)/ AKT signaling also involves TPA-stimulated NF- $\kappa \mathrm{B}$ transcriptional activity.

For many cutaneous diseases associated with chronic inflammation, such as acne, rosacea and atopic dermatitis, symptonic management of skin flare-up by anti-inflammatory agents is beneficial for quality of life. However, long term application of steroids is constricted due to side effects of skin atrophy, increased opportunistic infections and steroidinduced dermatitis. ${ }^{10}$ Use of calcenurin inhibitors like tacrolimus and pimecrolimus overcame some drawbacks of steroids, but their long term side effects are still unknown, although study indicated that up to 4 years of tacrolinus treatment of atopic dermatitis is safe. ${ }^{11}$ As a consequence, anti-inflammatory agents with reduced or little immunosuppression may be an option for chronic cutaneous inflammations therapy algorithm.

Telmesteine (Fig. 1A), ((-)-3-ethyl hydrogen $(R)$-3,4-thiazolidinedicarboxylate) has been conventionally used as a mucolytic in the treatment of respiratory-tract disorders through oral administration of $300 \mathrm{mg}$ dosage two or three times daily. ${ }^{\mathbf{1 2}}$ Telmestaine also inhibits elastase and collagenase and may be useful in the treatment of skin aging and psoriasis. ${ }^{13,14}$ In recent years, telmesteine has been incorporated into topical formulations for dermatitis. ${ }^{\mathbf{1 4 , 1 5}}$ However, the mechanisms underlying these topical anti-inflammatory effects of telmesteine on TPAinduced skin inflammation remain to be elucidated. 


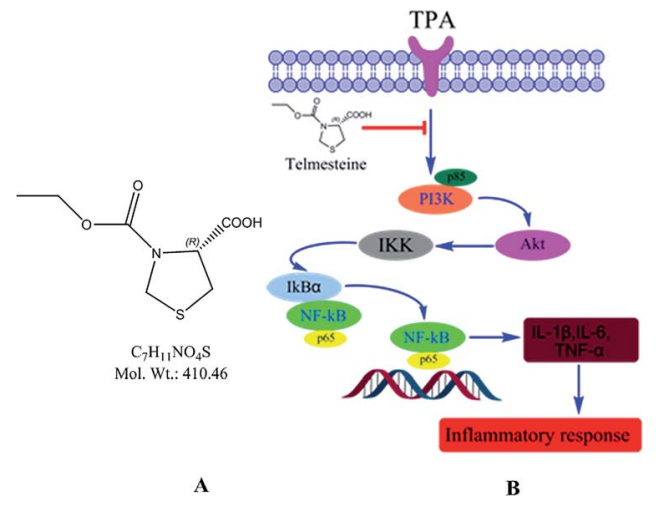

Fig. 1 Chemical structure (A) and a model of telmesteine modulation of TPA-induced signal transduction pathways in mouse skin in vivo (B).

Herein, we investigate some of the in vitro and in vivo antiinflammatory properties of telmesteine. Our results showed that telmesteine treatment resulted in an obviously decline of LPS-induced NO production in RAW264.7 cells and TPAinduced skin inflammation as assessed by skin edema and pro-inflammatory cytokines interleukin (IL)-1 $\beta$, IL-6, and necrosis factor-alpha (TNF- $\alpha$ ). Further analysis results demonstrated that the anti-inflammation properties of telmesteine were associated with its ability to inhibit activation of NF- $\kappa$ B by blocking phosphoinositide 3-kinase/protein kinase $\mathrm{B}$ (PI3K/ Akt)/I $\mathrm{B}$ kinase (IKK) activities.

\section{Material and methods}

\section{Material}

Telmesteine (99\%) was purchased from BOC Sciences. TPA was obtained from the Henan Cancer Hospital (Henan, China). IL$1 \beta$, IL-6, TNF- $\alpha$, anti-rabbit, anti-mouse horseradish peroxidase (HRP)-conjugated secondary antibodies, anti-Ser536 p65, antiphospho-Ser536 p65 antibodies, anti-Ser32 IкB- $\alpha$, antiphospho-Ser32 I B- $\alpha$, anti-IKK, anti-Ser473 Akt, antiphosphoSer473 Akt, anti-PI3K p85 and anti-phospho-PI3K p85 were purchased from Beyotime Biotechnology Co. (Beijing, China). The other chemicals used were in the purest form available commercially.

\section{Effects of telmesteine on lipopolysaccharide (LPS)-induced NO in LPS-induced RAW264.7 cells}

MTT and NO assays were carried out to evaluate the in vitro antiinflammatory properties of telmesteine. RAW264.7 cells $(2.0 \times$ $10^{5}$ cells per $\mathrm{mL}$ ) were cultured for $1 \mathrm{~d}$, followed by LPS (100 ng $\mathrm{mL}^{-1}$ ) treatment in the presence of different concentrations of telmesteine $\left(5,10,15,20 \mu \mathrm{g} \mathrm{mL}{ }^{-1}\right)$. After incubation for $1 \mathrm{~d}$, an MTT stock solution was added to the medium, followed by incubation for $1 \mathrm{~h}$. The absorbance was measured at $540 \mathrm{~nm}$. The nitrite as a stable end product of NO was measured using the Griess reaction. Sample $(100 \mu \mathrm{L})$ mixed with Griess reagent $100 \mu \mathrm{L}(0.1 \% N$-(1-naphthyl) ethylenediamide dihydrochloride and $1 \%$ sulfanilamide in $5 \%$ phosphoric acid), followed by spectrophotometric measurement at $550 \mathrm{~nm}$. Nitrite concentrations in supernatants were counted based on the sodium nitrite standard curve.

\section{Animals}

Female BALB/c mices at 5-6 weeks old were obtained from Guangdong Medical Laboratory Animal Center (Guangzhou, China). All animals were housed in a controlled atmosphere (25 $\pm 1{ }^{\circ} \mathrm{C}$ at $50 \%$ relative humidity) and with a $12 \mathrm{~h}$ light-12 h dark cycle. Animals had free access to food and water at all times. Animals were maintained in accordance with the guidelines of the Guangdong Medical Laboratory Animal Center, China, and approved by the institutional ethical committee (IEC) of Wuyi University.

\section{TPA-induced ear edema in mice}

For TPA-induced mouse ear edema model, ${ }^{\mathbf{1 6}, 17}$ both mice ears were topical treated with acetone or telmesteine with different concentrations respectively, $30 \mathrm{~min}$ prior to TPA $(0.008 \mathrm{nM}$ in acetone) treatment. Then the mice were sacrificed after $6 \mathrm{~h}$. Finally, ear punches of $6 \mathrm{~mm}$ diameter from mice ears were taken and weighed. The inhibitory effects (IE) $=[($ TPA alone $)-$ (test compound plus TPA)]/[(TPA alone) - (acetone alone) $] \times$ $100 \%$.

\section{Histological appearance of mouse ears}

Mice ears were removed in toto, fixed in $10 \%$ formalin, decalcified in EDTA buffer, subjected to a series progression of dehydration, and then embedded in paraffin. Samples were serially sectioned into $4 \mu \mathrm{m}$ and processed routinely for hematoxylin and eosin (H\&E) staining. The histological changes were observed under a microscope.

\section{Determination of IL-1 $\beta$, IL-6 and TNF- $\alpha$}

The expression of IL-1 $\beta$, IL- 6 and TNF- $\alpha$ were measured as described previously. ${ }^{16,17}$ Briefly, after incubated with $1.2 \%$ $\mathrm{H}_{2} \mathrm{O}_{2}$ in PBS, the deparaffinized skin sections were treated with the primary antibody of proliferating cell nuclear antigen at $4{ }^{\circ} \mathrm{C}$ overnight. After washed with PBS, the sections were incubated with a biotin-conjugated horseradish peroxidase antibody at $25{ }^{\circ} \mathrm{C}$ for one hour. Finally, the 3,3-diaminobenzidine tetrahydrochloride reactions were applied to produce the brown label in the epidermal tissue. The peroxidase was detected. For each section, the numbers of positive staining cells were counted in five different fields at both ends as well as in the middle.

\section{Assays of p65, p-p65, IKK, IКB $\alpha$, p-IКB $\alpha$, PI3k p85, p-PI3k p85, AKt and p-AKt}

The assay of NF- $\kappa \mathrm{B}$ transcriptional activity and PI3K/Akt/IKK signaling pathway were detected as described in our previous work. ${ }^{18}$ Briefly, the paraffin skin sections were made and then processed routinely for staining. The histological changes were examined under microscope. 


\section{Scoring the expression of biomarkers}

For each sample, $\geq 5$ ducts per histologic type were scored independently by two experienced investigators not aware of the identity of the specimens $(\times 200)$. Expression of IL-1 $\beta$, IL-6, TNF-

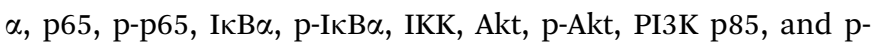
PI3K p85 were detected by the following semi-quantitative scoring system. ${ }^{19}$ The intensity of staining was scored as follows: 0 , no staining; $1+$, faint; $2+$, moderate; $3+$, strong. $1+$, $2+$, and $3+$ were recorded as 1, 2, and 3 points, respectively. The extent of staining was graded as follows: 0 , no staining; $1+$, $\leq 25 \%$ of cells positive; $2+, 26 \%$ to $50 \%$ of cells positive; $3+$, $\geq 51 \%$ of cells positive. ${ }^{20}$

\section{Statistical analysis}

The results are presented as mean \pm standard error of mean (S.E.M.). The statistical significance between the groups was calculated by one-way analysis of variance ANOVA followed by Dunnett $t$ test. $P$ values less than $0.05(P<0.05)$, were considered indicative of significance.

\section{Results and discussion}

\section{Effects of telmesteine on LPS-induced NO release}

NO, an important information molecule, is synthesized by NO synthase (NO) catalyzing L-arginine. In the inflammatory process, activated macrophages secrete large amounts of NO, which results in the injury of the surrounding tissue. The in vitro anti-inflammatory property of telmesteine was determined in LPS-induced RAW264.7 cells. As shown in Fig. 2A, telmesteine at concentration of $5,10,15$, and $20 \mu \mathrm{g} \mathrm{mL}{ }^{-1}$ had no obvious effect on RAW264.7 cells viability after LPS treatment (100 ng mL ${ }^{-1}$ ). Compared with controls, RAW264.7 cells treated with LPS alone showed significant induction of NO, while telmesteine treatment could significantly decreased the LPSinduced NO in RAW264.7 (Fig. 2B).

\section{Effects of telmesteine on TPA-induced mouse ear edema}

The first hallmark of skin inflammation skin is the increased skin thickening, which also is an indicator of processes occurring in skin inflammation, such as edema, increased vascular permeability, and proliferation of epidermal keratinocytes. ${ }^{\mathbf{2 1 , 2 2}}$ The in vivo anti-inflammatory effect of telmesteine was evaluated in a TPA-induced mouse ear edema model. As shown in
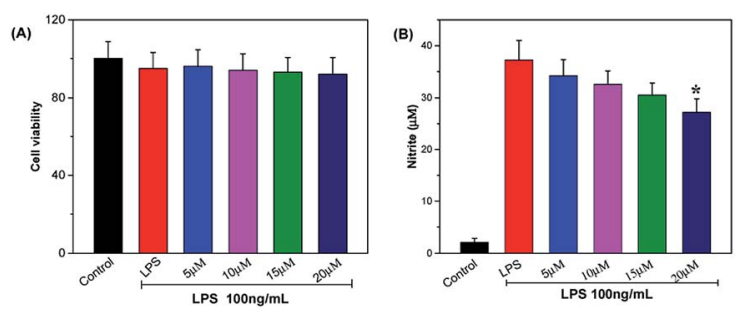

Fig. 2 Effects of telmesteine on LPS-induced cell viability (A) and NO in LPS-induced RAW264.7 cells (B). Data was expressed as mean \pm S.E.M. $(n=3) * P<0.05$ was compared with LPS-treated group.

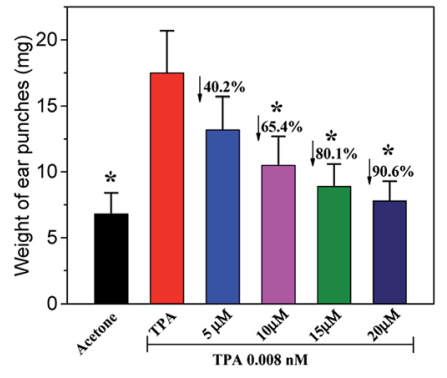

Fig. 3 Effects of telmesteine on TPA-induced mouse ears edema. The values were represented as the mean \pm S.E.M. $(n=3)$. ${ }^{*} P<0.05$ was compared with TPA-treated mice.

Fig. 3, topical application of TPA $(0.008 \mathrm{nM})$ alone would result in a markedly increase of mouse ear edema, then the average weight of TPA-treated ear punches increases from $6.8 \mathrm{mg}$ to $17.3 \mathrm{mg}$. Notably, topical application of telmesteine $(5-20 \mu \mathrm{M})$ markedly inhibited TPA-induced skin inflammation, with dosedependently affecting ear edema. Importantly, the $20 \mu \mathrm{M}$ dose caused a $90.6 \%$ decrease in the average weight of the ear punches.

\section{Histological appearance of mouse ears}

Fig. 4 illustrated the histological appearances of acetone, TPA, and telmesteine $(5-20 \mu \mathrm{M})$ groups, respectively. Compared to acetone-treated mice (Fig. 3a), topical application of TPA alone (Fig. 3b) caused an obviously inflammation response with clear evidences of ear edema and inflammatory cells infiltration. Moreover, topical application of telmesteine (5-20 $\mu \mathrm{M}$ ) (Fig. 4cf) significantly decreased inflammatory cells infiltration. And telmesteine at $20 \mu \mathrm{M}$ caused the most markedly morphological alterations, compared to TPA treated alone (Fig. 4f).

\section{Effect of telmesteine on TPA-induced pro-inflammatory cytokines expressions}

Cytokines are produced by cells induced with immunogen, mitogen and other stimulants. They have a variety of functions on regulation of immunity, hematopoiesis, cell growth and damaged tissue repairation. ${ }^{23-25}$ The pro-inflammatory cytokines produce various signaling molecules, which mediate pathogenesis of inflammation. ${ }^{26-28}$ Thus we assessed the inhibitory effects of telmesteine by analyzing the expression changes of IL-1 $\beta$, IL-6 and TNF- $\alpha$ using immunohistochemical analysis. As illustrated in Fig. 4b, topical application of TPA obviously increased the expressions of IL- $1 \beta$, IL- 6 and TNF- $\alpha$ compared with acetonetreated mice. In contrast, pretreatments with telmesteine notably reduced the expressions of TPA-reduced IL-1 $\beta$, IL- 6 and

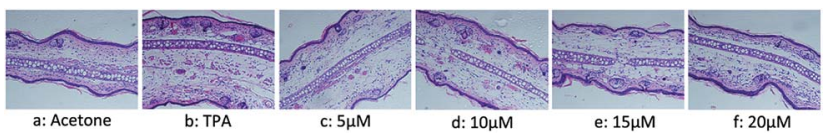

Fig. 4 Histological changes of TPA-induced mouse ear pretreated with apigenin (5-20 $\mu$ M). Magnification 200x. 
TNF- $\alpha$ (Fig. $5 \mathrm{c}-\mathrm{f}$ ). In addition, the IL-1 $\beta$, IL-6 and TNF- $\alpha$ upregulation induced by TPA administration were significantly inhibited by topical treated with telmesteine $(20 \mu \mathrm{M})$.

\section{Effects of telmesteine on TPA-induced NF-אB activation by targeting IKK}

NF-KB contained with Rel, p65, RelB, p50 and p52 is a early transcription factor can response to the harmful stimuli on cells at the first time. NF- $\kappa B$ has been recognized as one of the most important molecular targets in the prevention of inflammation and cancer. ${ }^{29,30}$ Many molecules involved in inflammation are regulated by NF- $\kappa$ B, including TNF- $\alpha$, IL-1 $\beta$, IL-2, IL-6, IL-8, IL-12, iNOS and COX-2. Notably, numerous reports have demonstrated that the increase of nuclear factor NF- $\kappa \mathrm{B}$ activation plays a critical role in the development and maintenance of cutaneous inflammatory diseases, such as psoriasis, atopic dermatitis, rosacea, and contact dermatitis. ${ }^{31,32}$ Therefore, drugs with inhibition on nuclear factor NF- $\mathrm{KB}$ activation are potential interest in the treatment of skin inflammatory diseases. Thus, we evaluated the effects of telmesteine on TPA-stimulated NF- $\mathrm{KB}$ activation in mouse skin. After stimulated by TPA (Fig. 6b), one of its functional active subunit-p65 mainly distributed in the cytoplasm is markedly evoked nuclear translocation to the nucleus. ${ }^{33,34}$ However the significantly increased expression of p65 is strongly inhibited by telmesteine pretreatment in a dose-dependent manner (Fig. 6c-f). Furthermore, telmesteine administration also significantly reduced the expression of phosphor-p65, which contributes to its transcriptional activity (Fig. 6c-f). These results indicated that telmesteine significantly suppressed TPA-stimulated NF- $\mathrm{B}$ promoter activity. Also the inhibition of NF- $\mathrm{KB}$ activation by telmesteine might explain its effects on the expression of IL-1 $\beta$, IL-6 and TNF- $\alpha$ in mouse skin induced by TPA.

Several experimental evidences convincingly certificate that phosphorylation of I $\kappa \mathrm{B}$ proteins including $\mathrm{I} \kappa \mathrm{B} \alpha$ is essential for
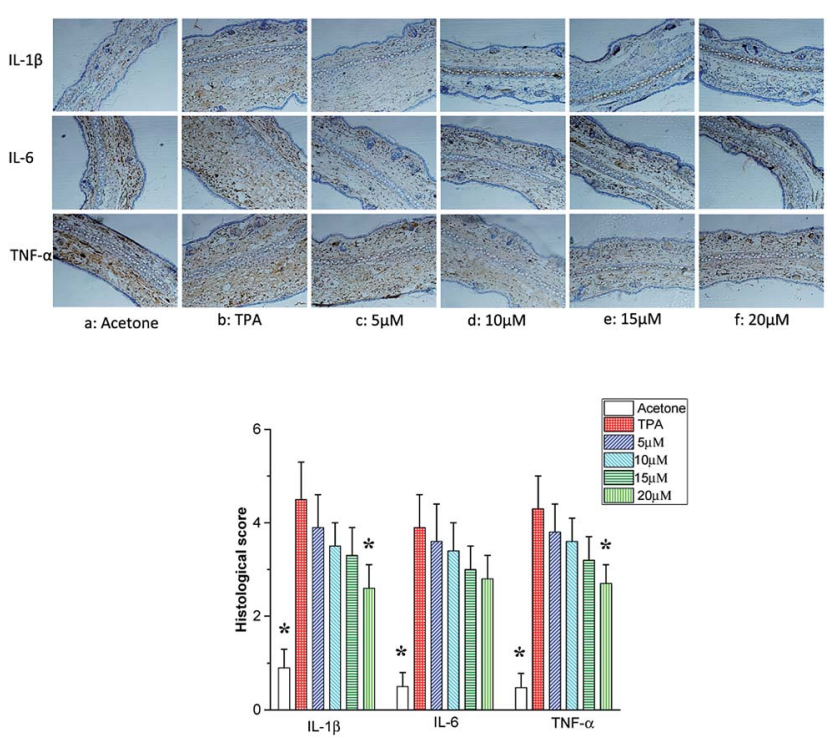

Fig. 5 Effects of telmesteine on TPA-induced expressions of IL-1 $\beta$, IL6 and TNF- $\alpha$. Magnification 200x. Data was expressed as mean \pm S.E.M. $(n=3) * P<0.05$ was compared with TPA-treated mice.
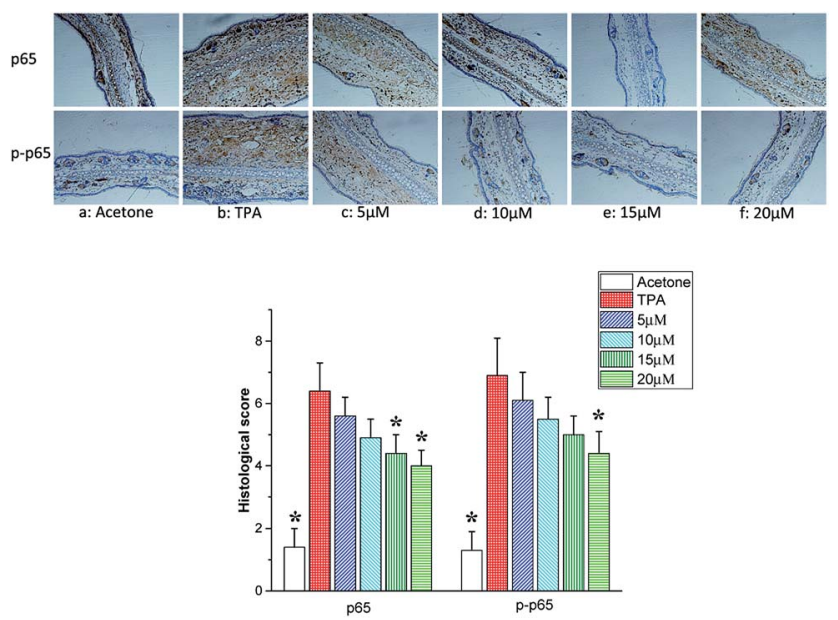

Fig. 6 Effects of telmesteine on TPA-induced expressions of p65 and p-p65. Magnification 200 $\times$. Data was expressed as mean \pm S.E.M. $(n=$ 3) $* P<0.05$ was compared with TPA-treated mice.

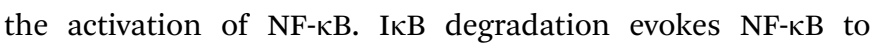
translocate to the nucleus. The I $\mathrm{B}$ kinase (IKK) is a complex of $\mathrm{IKK} \alpha$, IKK $\beta$ and IKK $\gamma$, which plays important roles in phosphorylating $\mathrm{I} \kappa \mathrm{B} \alpha$ and activating NF- $\kappa \mathrm{B} \cdot{ }^{35-37}$ As shown in Fig. $7 \mathrm{~b}$, TPA treatment resulted in the phosphorylation of $\mathrm{I} \kappa \mathrm{B} \alpha$ protein accompanied with its degradation. Telmesteine pretreatment significantly suppressed the degradation and phosphorylation of I $\kappa \mathrm{B} \alpha$ (Fig. 7c-f). Likewise, telmesteine pretreatment significantly inhibited the TPA-induced IKB kinases (IKK) activity in a dose-dependent manner (Fig. 7c-f).

\section{Inhibitory effects of telmesteine on TPA-induced activation of PI3K/Akt}

$\mathrm{NF}-\kappa \mathrm{B}$ molecule is also known to be regulated by PI3K/Akt signaling pathway, besides the regulation by $\mathrm{I} \kappa \mathrm{B} \alpha$ and IKK.
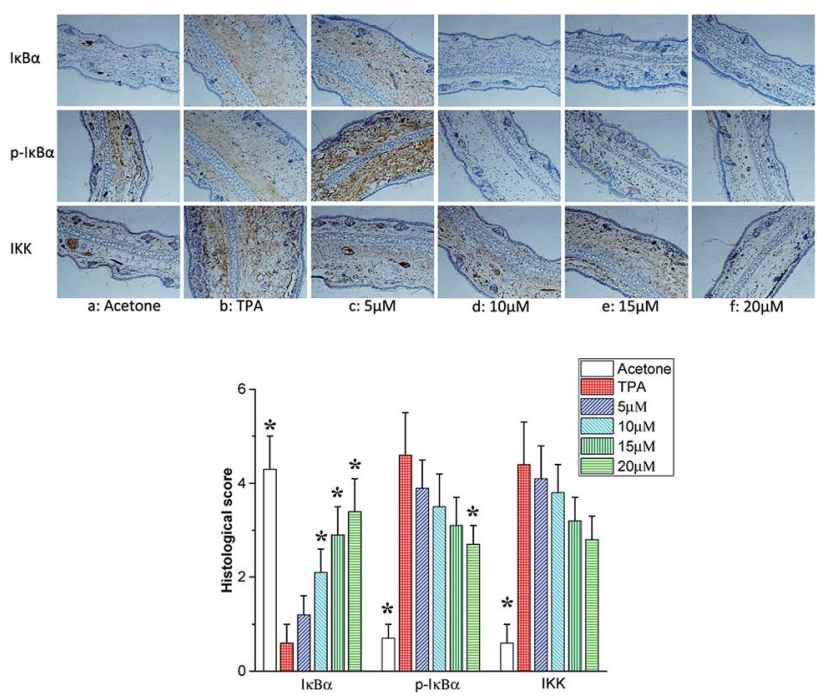

Fig. 7 Effects of telmesteine on TPA-induced expressions of $1 \kappa B \alpha, p$ $I \kappa B \alpha$ and IKK. Magnification 200x. Data was expressed as mean \pm S.E.M. $(n=3) * P<0.05$ was compared with TPA-treated mice. 

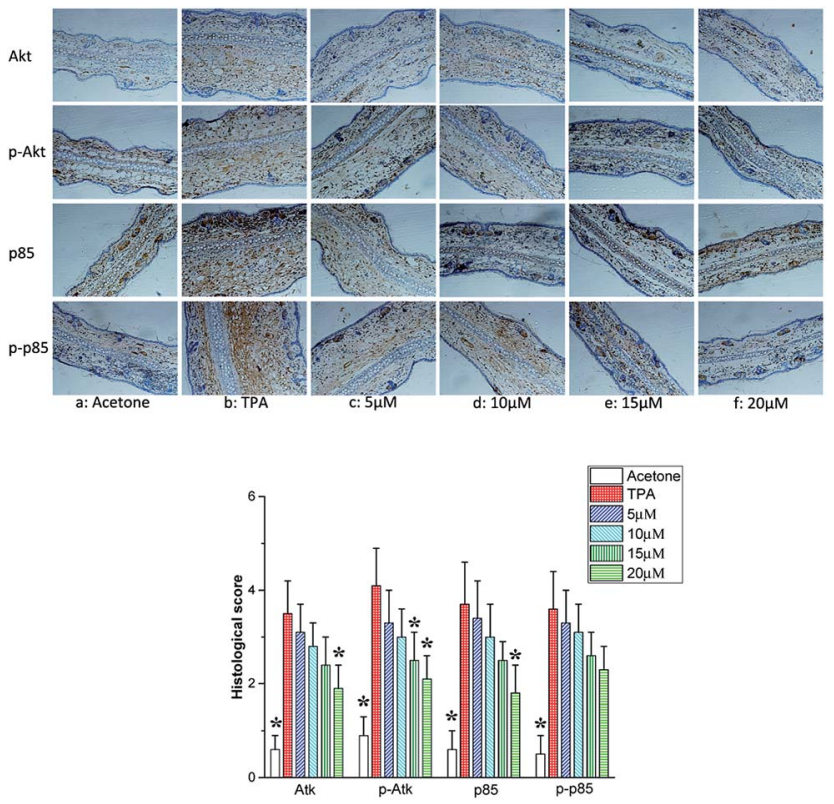

Fig. 8 Effects of telmesteine on TPA-induced expressions of p85, pp85, Akt and p-Akt. Magnification 200x. Data was expressed as mean \pm S.E.M. $(n=3) * P<0.05$ was compared with TPA-treated mice.

PI3K, an intracellular phosphatidylinositol kinase constituted with regulatory subunit of P85 and catalytic subunit of p110 plays an important role in the pathogenesis of inflammatory, tumor and metabolic diseases. ${ }^{38,39}$ AKT called protein kinase B is the direct target protein of PI3K. ${ }^{40}$ Activated PI3K/Akt signaling pathway results in the NF- $\kappa \mathrm{B}$ activation though the enhancement of $\mathrm{I} \kappa \mathrm{B}$ phosphorylation and degradation. ${ }^{\mathbf{4 1}}$ Furthermore, PI3K/Akt signaling pathway is closely related to the regulation and release of cytokines such as IL, TNF- $\alpha$ and IFN. ${ }^{42}$ Herein, the effects of telmesteine on PI3K/Akt signaling pathway were investigated. As shown in Fig. 8, TPA application caused markedly increases on expressions of p85, p-p85, Akt, and p-Akt. All our above data indicated that telmesteine exerts its anti-inflammatory properties by inhibiting activation of NF$\kappa \mathrm{B}$ by blocking PI3K/Akt/IKK activities (Fig. 1B).

\section{Summary}

In summary, the present study provides evidence that telmesteine exhibits strong anti-inflammatory properties. Telmesteine treatment could decrease LPS-induced NO production in RAW264.7 cells. Also telmesteine treatment could inhibit TPAinduced inflammatory (skin edema and pro-inflammatory cytokines (IL-1 $\beta$, IL-6, and TNF- $\alpha$ )) in mice. In addition, our data indicated that telmesteine exerts its anti-inflammatory properties by inhibiting activation of NF- $\kappa \mathrm{B}$ by blocking PI3K/ Akt/IKK activities. All results suggests telmesteine can be used as a potent anti-inflammatory agent for skin inflammatory and anti-inflammatory materials in cosmetics. Currently, the development of application of telmesteine in cosmetics is ongoing in our lab.

\section{Acknowledgements}

Financial support was provided by the Natural Science Foundation of Guangdong Province (2016A030310441 and 2016A030313006), the Youth Team Fund of Wuyi University (2016td01), and Youth Fund of Wuyi University (2015zk03 and 2015zk05).

\section{Notes and references}

1 R. Medeiros, M. F. Otuki, M. C. W. Avellar and J. B. Calixto, Eur. J. Pharmacol., 2007, 559, 227-235.

2 A. K. Maurya, M. Singh, V. Dubey, S. Srivastava, S. Luqman and D. U. Bawankule, Curr. Pharm. Biotechnol., 2014, 15, 173-181.

3 A. B. Gokhle, A. S. Damre, K. R. Kulkarni and M. N. Saraf, Phytomedicine, 2002, 9, 433-437.

4 J. Wu and C. C. Chu, J. Mater. Chem. B, 2013, 1, 353-360.

5 J. Wu and C. C. Chu, Acta Biomater., 2012, 8, 4314-4323.

6 G. K. Kumar, R. Dhamotharan, N. M. Kulkarni, M. Y. A. Mahat, J. Gunasekaran and M. Ashfaque, Eur. J. Pharmacol., 2011, 662, 63-69.

7 J. K. Kundu, Y. K. Shin and Y. J. Surh, Biochem. Pharmacol., 2006, 72, 1506-1515.

8 H. Hvid, I. Teige, P. H. Kvist, L. Svensson and K. Kemp, Int. Immunol., 2008, 20, 1097-1106.

9 M. Zielińska, T. B. Haddou, G. Cami-Kobeci, M. Sałaga, A. Jarmuż, M. Padysz, R. Kordek, M. Spetea, S. M. Husbands and J. Fichna, Eur. J. Pharmacol., 2015, 765, 582-590.

10 K. Hoffmann, T. Auer, M. Stiicker, A. Hoffmann and P. Altmeyer, J. Eur. Acad. Dermatol. Venereol., 1998, 10, 137142.

11 J. M. Hanifin, A. S. Paller, L. Eichenfield, R. Clark, N. Korman, G. Weinstein, I. Caro, E. Jaracz and M. J. Rico, J. Am. Acad. Dermatol., 2005, 53, S186-S194.

12 S. C. Sweetman, B. Pharm and F. R. Pharm, The Pharmaceutical Press, 2009, p. 1573.

13 C. Rumio and M. Mastrodonato, J. Am. Acad. Dermatol., 2008, 58, AB22.

14 R. Narins, C. Maas, Z. P. Lorenc and G. D. Monheit, J. Am. Acad. Dermatol., 2008, 58, AB19.

15 M. Mastrodonato, US Pat. 8431601 B2, 2013.

16 V. Stefano, D. M. Paolo, S. Rossana and L. Luisa, J. Drugs Dermatol., 2009, 8, 537-539.

17 W. F. Liu, Y. L. Li, K. Zhang and Z. Y. Du, Food Funct., 2015, 6, 3712-3719.

18 W. F. Liu, Y. L. Li, Y. Yue, K. Zhang, Q. Chen, H. Q. Wang, Y. J. Lu, M. T. Huang, X. Zheng and Z. Y. Du, Bioorg. Med. Chem. Lett., 2015, 25, 3044-3051.

19 M. C. Kraan, J. J. Haringman, M. J. Ahern, F. C. Breedveld, M. D. Smith and P. P. Tak, Rheumatology, 2000, 39, 43-49.

20 N. Ouyang, J. L. Williams, G. J. Tsioulias, J. J. Gao, M. J. Iatropoulos, L. Kopelovich, K. Kashfi and B. Rigas, Cancer Res., 2006, 66, 4503-4511.

21 B. J. Nickoloff, Y. Ben-Neriah and E. Pikarsky, J. Invest. Dermatol., 2005, 124, 10-14. 
22 T. S. Rao, J. L. Currie, A. F. Shaffer and P. C. Isakson, Inflammation, 1993, 17, 723-741.

23 C. Hauser, J. M. Dayer, F. Jaunin, B. de Rochemonteix and J. H. Saurat, Cell. Immunol., 1986, 100, 89-96.

24 A. Kock, T. Schwarz, R. Kirnbauer, A. Urbanski, P. Perry, J. C. Ansel and T. A. Luger, J. Exp. Med., 1990, 172, 16091614.

25 T. S. Kupper, D. W. Ballard, A. O. Chua, J. S. McGuire, P. M. Flood, M. C. Horowitz, R. Langdon, L. Lightfoot and U. Gubler, J. Exp. Med., 1986, 164, 2095-2100.

26 S. Singh and B. B. Aggarwal, J. Biol. Chem., 1995, 270, 1063110639.

27 N. G. Carlson, W. A. Wieggel, J. Chen, A. Bacchi, S. W. Rogers and L. C. Gahring, J. Immunol., 1999, 163, 3963-3968.

28 M. T. Huang, G. Ghai and C. T. Ho, Compr. Rev. Food Sci. Food Saf., 2004, 3, 127-139.

29 S. S. Han, Y. S. Keum, H. J. Seo, K. S. Chun, S. S. Lee and Y. J. Surh, Cancer Lett., 2001, 164, 119-126.

30 S. O. Kim, J. K. Kundu, Y. K. Shin, J. H. Park, M. H. Cho, T. Y. Kim and Y. J. Surh, Oncogene, 2005, 24, 2558-2567.

31 E. Zandi, D. M. Rothwarf, M. Delhase, M. Hayakawa and M. Karin, Cell, 1997, 91, 243-252.
32 Z. W. Li, W. Chu, Y. Hu, M. Delhase, T. Deerinck, M. Ellisman, R. Johnson and M. Karin, J. Exp. Med., 1999, 189, 1839-1845.

33 P. Viatour, M. P. Merville, V. Bours and A. Chariot, Trends Biochem. Sci., 2005, 1, 43-51.

34 Y. Kim and S. M. Fischer, J. Biol. Chem., 1998, 273, 2768627694.

35 M. Karin and M. Delhase, Semin. Immunol., 2000, 12, 85-98.

36 C. L. Carpenter and L. C. Cantley, Curr. Opin. Cell Biol., 1996, 8, 153-158.

37 M. Karin, Oncogene, 1999, 18, 6867-6874.

38 J. K. Kundu and Y. J. Surh, Mutat. Res., Fundam. Mol. Mech. Mutagen., 2005, 591, 123-146.

39 L. C. Cantley, Science, 2002, 296, 1655-1657.

40 K. M. Nicholson and N. G. Anderson, Cell. Signalling, 2002, 14, 381-395.

41 H. Shimamura, Y. Terada, T. Okado, T. Hiroyuki, S. Inoshita and S. Sadak, J. Am. Soc. Nephrol., 2003, 14, 1427-1434.

42 S. K. Selvaraj, R. K. Giri, N. Perelman, C. Johnson, P. Malik and V. K. Kalra, Blood, 2003, 102, 1515-1524. 